\title{
Translanguaging as An ESL Learning Strategy: A Case Study in Kuwait
}

\author{
Rahima Sayed Sulaiman Akbar ${ }^{1} \&$ Hanan Ali Taqi ${ }^{1}$ \\ ${ }^{1}$ The Public Authority for Applied Education \& Training (PAAET), College of Basic Education (CBE), The English \\ Department (TED), Ardiya, Kuwait \\ Correspondence: Rahima Sayed Sulaiman Akbar, The Public Authority for Applied Education \& Training (PAAET), \\ College of Basic Education (CBE), The English Department (TED), Ardiya, Kuwait.
}

Received: August 1, 2020

Accepted: August 18, 2020

Online Published: August 25, 2020

doi:10.5430/ijhe.v9n6p54

URL: https://doi.org/10.5430/ijhe.v9n6p54

\begin{abstract}
In the domain of teaching bilingual students, the issue of using the first language in a second-language based class has been widely controversial. While some studies have questioned the method of moving between the two languages, Translanguaging, others found it highly beneficial. Here we aimed to investigate the effect of Translanguaging on the learner's performance and language learning. 34 consenting female students of English participated in oral and written exercises pre-and-post the use of Translanguaging. A short questionnaire was answered afterwards to elicit the participants' perception on the use of Translanguaging as part of their classwork. Even though students did not believe that their ability to alternate between the two languages has placed them in a significantly enhanced comfort zone, their higher grades post-Translanguaging indicate Translanguaging enhanced their understanding and enabled them to achieve higher levels of knowledge processing. Nevertheless, the participants' language was not significantly affected by the process. Overall, we can conclude that Translanguaging in a bilingual classroom is effective in fully understanding the topic and the information provided, yet it does not help improve language proficiency.
\end{abstract}

Keywords: translanguaging, bilingualism, ESL, pedagogy, higher education, language, English, Arabic

\section{Introduction}

\subsection{Setting the Scene}

As we are living in a highly globalised world, bilingualism (and multilingualism in many cases) is becoming the norm. Populations around the globe are interconnected through virtual communications if not physical. As a result, the field of applied linguistics has also rapidly moved from considering bilingualism a threat to the individual's brain as well as the community's identity (Smith, 1939), into perceiving it as a scaffolding mean of communication and strategic teaching method (Yamat et al. 2011). Applied linguistics has, then, moved into 'a spontaneous, everyday way of making meaning, shaping experiences' that builds today's technological advances and our more fluid identities into a bilingual's 'brain activity' (Lewis \& Baker, 2012: 641). Such changing perspective has also its repercussions in the discipline of language teaching in general, and teaching English to speakers of other languages (TESOL) in particular. Whether to preserve the learner's mother tongue while exposing the learner to the minimal amount of L2, submerge the learner into L2 to ensure the optimal exposure to the target language, or shuttle between the learner's mother tongue and the target language so long as it facilitates the learning of the target language (ensuring the community's linguistic identity stays entact), have constantly been disputed amongst language teachers. A bilingual Chinese/English teacher stated in her personal communication account:

If I speak English to these kids, then they won't understand me. If I speak Chinese, then they won't understand the text and they won't be prepared. I just don't know what to do. So I speak both (March, 19, 2006).

In higher education institutes in Kuwait, where most professors and students speak Arabic as their mother tongue, and English as their second language, professors of various English language disciplines have always expressed a similar concern in teaching content courses in English to Arab bilingual college students. Thus, different language strategies have been implemented in ESL classrooms, depending on the students' linguistic abilities in L1 and L2 (balanced vs. emerging bilinguals), the nature of the taught courses, as well as the linguistic perspectives of the course teachers. 


\subsection{Translanguaging: A Historical Sketch}

Teaching English to speakers of other languages (TESOL) has been foregrounded in monolingual approaches for decades, aiming to push towards teaching English to support students' social and academic purposes, though very often taking no notice of their linguistic backgrounds (Kleyn \& Garcia 2019). Pedagogically, teachers were focusing on teaching languages as structural systems that comprised a set of skills rather than a practice (Pennycook, 2010). With the goal of achieving a native like proficiency, students' home languages were banned in ESL classrooms. According to Garcia (2009), the native speaker myth led to empowering advanced English speakers, while oppressing emerging bilinguals.

During the later decades of the $20^{\text {th }}$ century, linguists moved from viewing the alternation between the different language systems as a deviation from the norm (Weinreich, 1953) into the concept of 'code-switching' where the alternation was viewed as systematic but never haphazard (Auer, 1999).

In the early $21^{\text {st }}$ century, code-switching became further positively viewed by sociolinguists, as a safe conduct that may well facilitate the target language comprehension (Martin, 2005).

Later, when the $21^{\text {st }}$ century globalization reached its ultimate form due to the development of technology and internet, multilingualism started to replace monolingualism as the norm. Alongside that shift, sociolinguists began challenging the concept of studying bilinguals' behaviours and practices via the lens of named languages (Kleyn \& Garcia, 2019), viewing named languages as the formulation of the western world (Makoni \& Pennycook, 2007). The new stance has resulted in looking for terms that capture the dynamic nature of the bilinguals' communications, hence, translanguaging came into existence (Garcia \& Li Wei, 2014).

The established term 'Translanguaging' is a word that combines three morphemes; the prefix 'trans' to imply 'transcending', that is, moving beyond; 'language' to imply a tool of communication; 'ing' to imply that the term is a dynamic act rather than a static system ( $\mathrm{Li} \mathrm{Wei}, 2011)$. Rather than viewing the languages as separate systems of codes, translanguaging views the way bilinguals communicate as utilising one integrated unitary system, from which the speaker selects from his/her linguistic repertoire the best features for the communicative act. It is when the bilingual speaker shares similar linguistic features of the bilingual audience that would make translanguaging more visible (Otheguy et al. 2018). The term originates from the Welsh word 'trawsieithu' established by Cen Williams in 1980 to describe the systematic implementation of two languages in one lesson. The term has been then translated into 'translanguaging' by Baker (2001), to describe an intentional shuttling between the language of input and the language of output within one classroom setting.

\subsection{Translanguaging or Code-Switching}

Translanguaging has initially been coined with code-switching (Garcia, 2009). However, at a later stage, the two concepts were distinguished in theory and practice. Theoretically, Translanguaging presupposes a hetroglossic point of view, where bilinguals operate their entire linguistic repertoire to make meaning. Code-switching, however, expresses a monoglossic point of view, with the bilinguals alternating between two linguistic systems (Garcia \& $\mathrm{Li}$ Wei, 2014). Additionally, Translanguaging is foregrounded into Cummin's (1979) theory of 'interdependence', claiming the level of proficiency in L2 bears down on the learner's development in L1 (Garcia \& Wei, 2014). Code-switching is, differently, perceived to be the product of L1 interference, mostly regarded as having a negative influence in second language teaching and learning (Alhawary, 2018).

In practice, Translanguaging has been established as a pedagogical strategy in language teaching. Code-switching on the other hand signals the switching back and forth between languages in all types of situational contexts (Nagy, 2017), 'rarely institutionally endorsed or pedagogically underpinned' (Greese \& Blackledge, 2010: 105). When utilised in classroom settings, code-switching has been viewed as 'embarrassing', 'dilemma-filled', 'feelings of guilt', 'squandering our bilingual resources' as the languages 'contaminate' one another (Creese \& Blackledge, 2010: 112). Instead, Translanguaging is perceived to add flexibility in pedagogic classroom approaches, where 'ideas are more easily conveyed, understood, and relayed (Lewis et al. 2012: 649).

On another note, the concept of Translanguaging has recently caught the attention of the educationalists in North America and in Europe. As a result, the concept has expanded from' pedagogical practices to everyday cognitive processing, from classroom lessons to all contexts of a bilingual's life' (Lewis et al. 2012: 647). It is against this background that the term of Translanguaging has been extended into how bilinguals make sense of their worlds through the deployment of the two languages in a bilingual community 'if properly interpreted and practiced in schools, as a means to enhance pupils' cognitive, language and literacy abilities' (Lewis et al. 2012: 647). As such, (Garcia, 2011) draws a distinction between code-switching, translation and Translanguaging, in that, unlike 
code-switching and translation, Translanguaging 'is not only a way to scaffold instruction, to make sense of learning and language; rather, Translanguaging is part of the meta-discursive regimes that students in the twenty-first century must perform' (p. 147). With this background, bilingual teachers and students should perceive their natural Translanguaging practice as a valuable (rather than a shameful) tool and utilise it as an effective teaching method in bilingual classrooms (Garcia, 2009a).

\subsection{Translanguaging in Foreign Language Teaching}

Teaching English in an ESL context has been moving across two extremes; on one hand, traditional teaching methods, such as, Grammar Translation method consider learners' L1 as a facilitator in learning L2. From another point of view, some teaching methods recommended a strict avoidance of using L1 in an ESL classroom (such as the Audio-lingual approach), arguing that it would cause bad habit formation which would possibly interfere in the target language learning (Harmer, 2001). Between the two extremes, there are a number of ESL teaching methods, ranging between different levels of tolerance of using L1 in L2 learning (Yavus, 2012).

Translanguaging in education refers to 'using one language in order to reinforce the other, in order to increase understanding and in order to augment the pupil's activity in both languages' (Williams, 2002, qtd by Lewis et al. 2012: 40). In his account on Translanguaging in foreign language teaching, Baker (2011) introduces promoting a deeper understanding of the subject as a potential benefit. In this regard, it is argued that Translanguaging is an effective way of enabling this:

In a monolingual teaching situation... whole sentences or paragraphs can be adapted out of a textbook, from the internet...without real understanding. It is less likely to do this with "Translanguaging". To read and discuss a topic in one language, and then to write about it in another language, means that the subject matter must be processed and "digested". (Baker, 2011: 289).

Another benefit of Translanguaging in the TESOL arena is that it develops the learners' weaker language, as 'it may prevent them from undertaking the main part of their work through the stronger language while attempting less challenging tasks in their weaker language'. As such, Translanguaging develops the students' academic language skills in both L1 and L2, 'leading to a fuller bilingualism and biliteracy' (Baker, 2011: 290).

Also, Translanguaging facilitates home-school links and co-operation, especially when the learner is educated in a language other than the parents'. This occurs when the learner intensifies what has been learned in one language in school through a discussion with the parent in the home language. Another advantage of the use of Translanguaging is the way it may help the integration of advanced bilinguals with emerging bilinguals in the same classroom.

At an individual level, Estyn (2002: 1) replaces Translanguaging with the term 'dual literacy'. Her paper outlines the advantages of Translanguaging as 1. Refining an individual's ability to think, understand and internalise information in two languages; 2 . Developing flexibility of mind and a positive perspective towards other languages and cultures; 3. Enabling individuals to effectively use and alternate between L1 and L2, mimicking the way people practice presenting information in nowadays most job circles.

According to Lewis et al. (2012: 650), the effectiveness of Translanguaging as a classroom practice is 'still only beginning to be understood...yet to be researched, evaluated, and critiqued'. Poza (2017) reported that the vast majority of the increasing literature on Translanguaging between 2011 and 2017 were focused on PreK-12 education, but less on adult education. Thus, Mazak and Caroll (2017) called for the implementation of the Translanguaging approach at colleges and universities. Kleyn and Garcia (2019) present different ways Translanguaging can be implemented into ESL classrooms, with the purpose of developing English while also grasping the content. The key to a successful implementation of Translanguaging in an ESL context, they add, is to provide bilinguals with directions in their home language (possibly through peers assisting each other) to ensure the right start. Distinguishing between an ESL lesson's process and product, and how the students' language in each lesson, is also essential at an early phase of Translanguaging. For instance, by allowing the students to translanguage during the process, learners are enabled to use their entire linguistic repertoire to develop a full understanding of the topic. This is called Ttranslanguaging in the process phase. Translanguaging in a product phase, is related to what students create at the end of the topic; teachers must determine at an initial stage whether or not only English could be used, whether the product is a written account or an oral presentation for a bilingual audience. Additionally, incorporating Translanguaging in an ESL assessment phase is also critical in the Translanguaging approach. As such, Translanguaging introduces a fair assessment of what the students know rather than 'asking them to show their knowledge with linguistic features they have yet to acquire or by suppressing certain features' (p. 76).

Krause and Prinsloo (2016) have moved one step further as they claimed the essence of incorporating 
Translanguaging in the country's national educational policies to obtain its potential benefits. The findings imply that teachers naturally employ Translanguaging whenever the classroom context calls for it. Nonetheless, 'the potentially positive pedagogic effect of their translingual teaching is stifled by rigid, separatist language ideologies that inform school management...language policy and resulting assessment practices' (p. 355), where teachers' language practices and higher ideological constraints 'paralyse each other.'

In the Arab World, research on Translanguaging seems to be very scarce. To the knowledge of the researchers of this study, only a handful of studies have tried to document the educational benefits of Translanguaging in ESL contexts amongst Arab bilingual learners. In one study, the deployment of Translanguaging in an Arabic/English setting has been researched in the higher education at UAE. Findings indicate that Emirati students practise Translanguaging between Arabic and English and they relish doing so, despite their overt views advocating for keeping languages as separate entities (Palfreyman \& Al-Bataineh, 2018).

In another study, Al-Bataineh and Gallagher (2018) investigate attitudes of bilingual future teachers towards Translanguaging between languages and dialects when writing stories for bilingual young learners in a course of Children's Literature at an English/Arabic bilingual university in UAE. The findings indicate that future teachers held 'paradoxical' attitudes towards Translanguaging as the linguistic ideologies in the country played a crucial role in determining whether to accept or reject Translanguaging in a writing task (p. 2).

Also Hassan and Ahmad (2015) observed how teachers and students combine and alternate between Arabic, Urdu, Sylheti and English when engaged within the curriculum content to demonstrate how a variety of languages can be employed effectively within classroom settings in a private Islamic secondary school in UK. The study demonstrated in practical terms the potential advantages of Translanguaging. Park (2013) reports that Translanguaging as a multilingual practice is still practiced limitedly. He believes it lacks concrete sets of teaching strategies to facilitate language learning as well as academic achievement.

In Kuwait, a study conducted by Taqi and Shuqair (2014) investigated the improvement of the linguistic proficiency of students studying in the English department (the same department under investigation in this study) pre-and-post entry to the college. The researchers gave 50 graduating students the entrance exam they took when entering the department. Their results showed that while different methods of teaching for four years were implemented (Translanguaging being one), the students' already-low language abilities did not improve.

\subsection{L1 or L2? A dichotomy in English Teaching and Learning in Kuwait}

English has progressively gained its unique status in Kuwait, due to a number of socio-economic and political reasons (Dashti, 2015; Akbar, 2018; Alazmi, 2017). College students, as well as professors - English major, are placed under the pressure of conducting all their communications (whether written or spoken) in English only, in and off classroom settings. Intrinsically, the idea of 'Translanguaging' might be strongly opposed by educators within the ESL discipline, who tend to reject the concept of using L1 in an ESL context. It should be noted at this point that research on ESL teachers' attitudes towards using L1 in L2 contexts in Kuwait have generally expressed extremely negative attitudes towards using L1 in their ESL classroom instructions. For example, a study investigating English teachers' use of L1 when teaching college students in Kuwait, has shown that while teachers, in practice, utilised L1 in their teaching for various affective, sociolinguistic and psycholinguistics reasons, they tend to accuse those who did as being 'guilty of causing a potential loss of L2 exposure', 'making the class a waste of time', and as a result, 'should be avoided at any cost' (Alrabah et al., 2015). Also, since the establishment of the English Department at the College of Basic Education (the setting of the current study), the general atmosphere has been an intense discouragement of using L1, in and off classroom setting. For instance, amongst the professors in the department, a senior professor posted a sign at the entrance of the department, stating an 'English-only speaking zone', based on which students of the department are allowed to converse only in English, despite the fact that all staff members and students share Arabic as their mother tongue. As such, this research is an urgent call for the educators of the department, as well as those of similar ESL contexts, to revise such inherited beliefs and ideologies of a strict avoidance of using L1 in-and-off classroom settings.

The present study is an answer for several calls from sociolinguists and language educators to fill the literature gaps on the topic of Translanguaging, particularly in an Arab ESL context.

\subsection{The Present Research Scope}

The current study is an ambitious attempt to find out whether shuttling between the two languages of the students' linguistic repertoire would enhance the students' cognition of the learned content and leads to a better performance on an assigned task. This "shuttling" attempt is defined by Baker (2001) as 'Translanguaging' a term which describes 
the intentional shuttling between the two languages of the learner within a classroom setting to reach the most favourable outcome.

We aim to investigate whether 'Translanguaging' enhances the bilingual students' content learning and performance, through addressing the following research questions:

1) Does 'Translanguaging' enhance the bilingual students' content learning and performance?

2) To what extent does 'Translanguaging' develop the learners' English language?

3) What are the language learners' attitudes towards 'Translanguaging' as an ESL teaching method?

\section{Research Design \& Methodology}

\subsection{Method of Data Collection}

This research adopts a sequential exploratory mixed study design, whereby three tools were utilised for data collection:

a. Three online articles on the topic of 'Translanguaging' presented in Pdf file format and uploaded into the assignment tool in Teams.

b. Two video-conferencing sessions (via Teams) to initiate rounds of group discussions on the topic of 'Translanguaging'.

c. Two assigned tasks of written accounts on the topic of 'Translanguaging' to assess participants' performance during pre/post translanguaging.

d. A digital questionnaire via 'Forms Microsoft' to obtain participants' views on the implementation of 'Translanguaging' in teaching and learning the topic.

\subsection{Setting of the Study}

The study was conducted at the English department at the College of Basic Education in Kuwait. The department's mission is to teach and train female Kuwaiti cadres for the English language teaching profession, to fulfil the growing demands and requirements of the Ministry of Education. Accordingly, enrolees are presented with four basic skill courses to improve their English proficiency, alongside many other courses of teaching methods, applied linguistics theories and practices, and English literature, many of which, contain advanced scientific content, solely introduced in English textbooks and resources (see a copy of a detailed major sheet in the study's appendix A).

\subsection{Participants}

The study employed a sample of 34 all-female Arab/English bilingual students, currently involved in a psycholinguistic course as part of the required courses at the English Department in the College of Basic Education in preparation for future teachers of English in Kuwait. The participants $\left(3^{\text {rd }}\right.$ and $4^{\text {th }}$ year students) presented various competence levels in English as a second language. Age-wise, the majority ranges between the ages of 20-25, with only 3 whose age ranges between 26-30, and two at the age of 36 .

\subsection{Procedure}

The study was conducted in two phases. During the first phase of data collection, participants were prompted to read three articles on the topic of Translanguaging as an ESL teaching approach. Six groups of 5/6 ESL learners were formed, directed to meet and discuss the topic (in English only) in video conference sessions guided by the course professor (the main researcher) using 'Teams' platform. Following the group discussion sessions, each student was assigned to produce an account on the topic in English. The task was guided with three levels of questions:

a. Factual question (level one): can be answered explicitly by knowledge contained in the text (e.g. what is 'Translanguaging'?).

b. Inferential question (level two): can be answered through analysis and interpretation of specific parts of the text (e.g. list a number of advantages and disadvantages of 'Translanguaging' as an ESL teaching method in an elementary school in Kuwait).

c. Universal question (level 3): raised by ideas from the text (e.g. as a future teacher of English in the schools of Kuwait, how would you teach the skill of writing for ESL students at a high school?)

After a week interval, a second series of video conference sessions were administered by the main researcher, where students were given the freedom to translanguage the topic in English and/or their mother tongue.

The groups were then prompted to write a second account on the topic in English only. The two accounts were Published by Sciedu Press 
compared and assessed by the same researcher (main researcher) to find out how well the students were able to understand the topic and write about it.

In phase 2, the students were asked to fill a short questionnaire designed via 'Microsoft Forms' to elicit the participants' attitudes and feelings on the Translanguaging approach as a pedagogic learning approach. The questionnaire included the following four items, to be rated on a five point-Likert scale:

1) Discussing the topic in English was comfortable.

2) It was easy to convert the topic from English into my mother tongue in the second session.

3) I fully understood the topic after reading and discussing it in English.

4) I fully understood the topic after discussing it in English and/or my mother tongue.

\section{Study Results}

\subsection{Performance Level}

Students' performance was assessed during pre-and-post-Translanguaging sessions based on their performance in the two written tasks. A rubric of 5 points was established for each section, with a total of 20 points per each student's report:

a. Section 1 covers the knowledge level question, namely, 'What is Translanguaging?'

b. Section 2 answers the referential level question, namely, 'List a number of advantages and disadvantages of 'Translanguaging' as an ESL teaching method in an elementary school in Kuwait'.

c. Section 3 answers the universal level item, namely, 'As a future teacher of English in the schools of Kuwait, how would you teach the skill of writing for ESL students at a high school?'

d. A final 5 points rubric item was allocated for the language proficiency of the student's report.

Analysis of the mean scores across the four rubric items shows more intense variability in the students' performance along the three sections of factual, referential, and universal content, during the pre-Translanguaging as opposed to post-Translanguaging performed tasks. Such variability tends to gradually widens along the factual content, referential content, and universal content.

Results of the post-Translanguaging assignments however tend to be flattened, showing very slight to no variability at all. As for the language proficiency, there seems to be no significant effect of Translanguaging on the students' performance (see Figure 1 below).

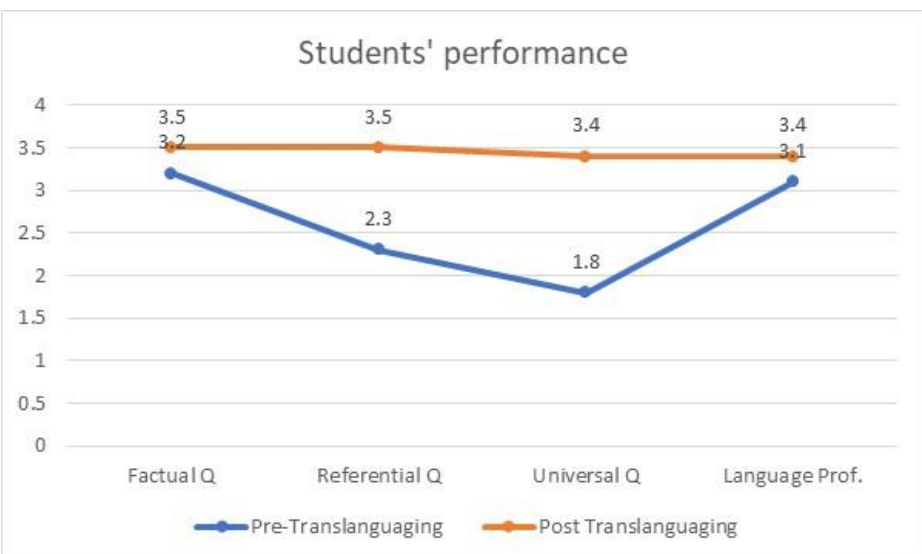

Figure 1. Assessment results of students' written tasks pre/post Translanguaging

\subsection{Views on Translanguaging}

Results of the questionnaire indicate the following views and thoughts as were expressed in how the students reflected on translanguaging as a learning strategy:

a. Students show moderate comfort, with a mean score of 3.1 when discussing the topic in English.

b. Students also show moderate ability in converting the discussion on the topic into their L1 (3.4).

c. Students show low-to-moderate understanding at a level of 2.7 of the learned topics in the pre-translanguaging assessed tasks. 
d. Students show a big jump in their understanding of the topic in the post-translanguaging assessed tasks, with the score reaching 4.5 out of 5 points. Figure 2 below shows the mean scores of the students' responses to the questionnaire items.

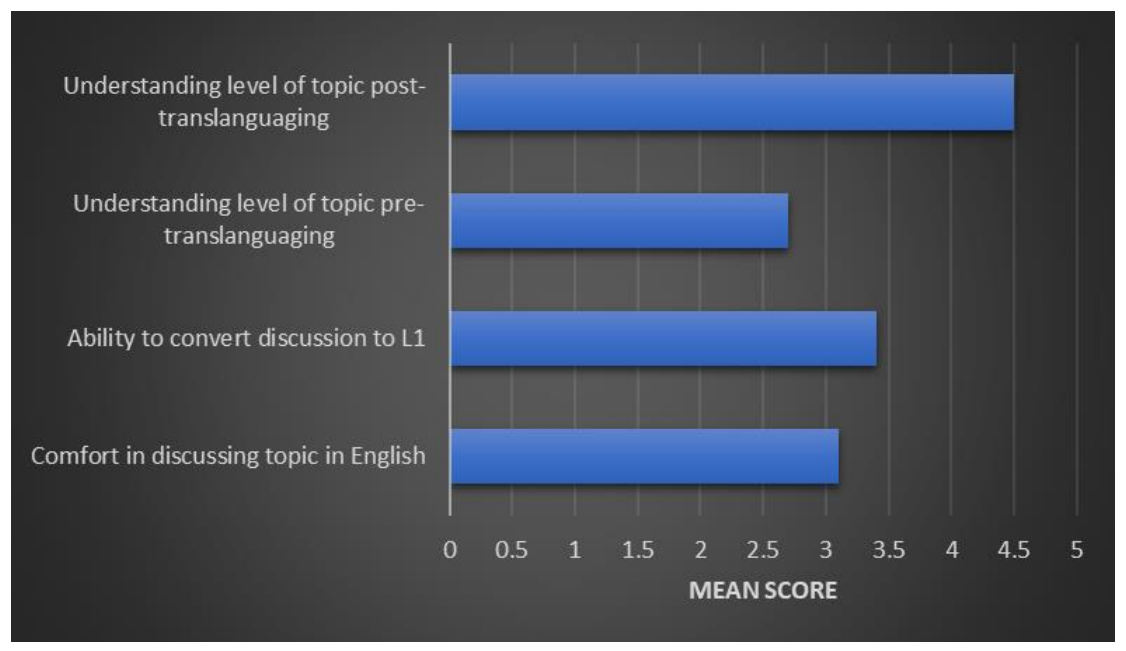

Figure 2. Students' responses to questionnaire items

\section{Discussion}

The current study investigates the effect of Translanguaging in an ESL context based on a call for evaluating the usefulness of Translanguaging in colleges and universities (Mazak \& Caroll, 2017), and the need of inserting Translanguaging in bilingual classrooms (Kleyn \& Garcia, 2019). The investigation consisted of pre- and post Translanguaging exercises, oral and written. The work presented by the participants was evaluated and graded. The exercises were followed by a questionnaire that would seek the students' perspective on the use of Translanguaging as part of the classwork context.

The written exercises were designed at a three-level scale of understanding. The results reflected minor improvement in the results of the first level which addresses the basic level of information processing (factual questions). In this part, students did not seem to have much trouble answering the question. However, when the questions focus on inferential information which address the second level of thinking, the difference becomes higher. When the third level of thinking was targeted, acquired from universal questions, the post-Translanguaging average grade appeared to be significantly higher than the pre-Translanguaging average results. This finding goes hand in hand with previous research on Translanguaging in an ESL context that found that since the learner uses his/her entire linguistics repertoire in Translanguaging to understand the concepts presented, s/he processes the information completely and on all learning levels (Baker, 2011; Kleyn \& Garcia, 2019). As Baker (2011) noted, the information is processed and "digested" when it is read and discussed in one language, probably the one the students are more comfortable using (L1). Then, the students attempt to answer in the second language. The results show that these steps of processing develop a deeper ability to process information, hence the highest difference in the average grade was found in the thinking level that required a reflection of ideas and individuality, a production of complete understanding of the concepts presented.

While Translanguaging achieved high thinking levels, it did not appear to affect the students' language. The results show a mere raise of $0.3(6 \%)$. This finding, however, seems to disagree with Baker (2011) who believed that one of the advantages of Translanguaging was the improvement of L1 and L2. It should be emphasized though, that any expectations of linguistic progression within such a limited task in content and time would be highly unrealistic. We, therefore, propose that for Translanguaging to gain its linguistic benefits, it should be implemented across a broad spectrum of the processes of teaching and learning. It should also be born in mind that, while we acknowledge that the amount of time to implement this study might have been too short to positively affect the students' language proficiency, Taqi and Shuqair (2014) have also shown that the students who have studied four years in the same department, and were taught by the same staff have shown no significant improvement in their linguistic abilities. Their finding was associated to the fact that the majority of students have medium to low English proficiency levels to start with, which could also indicate that time might have not played a role in the insignificant language level improvement of the present study's sample. 
As for the questionnaire results, it appears that the students were moderately comfortable in discussing the topic in English (L2). A slightly higher comfort score (from 3.1 to 3.4) might also indicate an enhanced comfort zone when the topic was discussed in the students' mother tongue (L1), yet not reaching the expected level. While it was expected that the students would feel highly comfortable alternating between languages to reach a prefect understanding of the topics (Estyn, 2002), this study showed no significance in the students' contentment in the use of either language. Nevertheless, the students reflected significantly less confidence in their understanding of the topic before the use of Translanguaging compared to their understanding after Translanguaging. This shows that, as most studies have found, not only do students feel more confident in performing their assigned written tasks, when given the chance to translanguage, but also they do gain more advanced knowledge processing abilities (Estyn, 2002; Baker, 2011; Kleyn \& Garcia, 2019).

The findings of the study propose that, although the main goal of ESL classes is to improve students' English proficiency, attempts to police an English-only atmosphere should be discouraged. Teachers' stance is also essential in how successful the implementation of 'Translanguaging' in any ESL context could be. Kleyn and Garcia (2019: 73) propose, 'for Tanslanguaging to live up to its full potential an educator must view all linguistic features and practices of any given student as a resource in general and specifically for their learning'.

To readdress the present study questions, the findings signal a noticeable level of progression in the bilingual students' content learning and performance. Nevertheless, Translanguaging seems to have not shown the expected language ability improvement (a finding that should be investigated further in future studies within a suitable time frame). Attitudes towards Translanguaging in an ESL context tends to be positive in general, placing ESL students in a slightly favourable comfort zone, empowering ESL learners with confidence and more advanced thinking abilities, that would improve their task performance in relation to content processing.

\subsection{Study Limitations}

While this study aimed to fill the gap in research implemented on Translanguaging in higher education, it has only been conducted on female participants. Future studies with larger numbers of participants and both genders would be favourable to reassure the finding of this study. Future studies might also investigate the effect of Translanguaging on students of higher L2 proficiency to be able to acknowledge the linguistic effect of Translanguaging in a different context.

\section{Conclusion}

The current study has shed light on the planned use of Translanguaging in an ESL classroom, showing its effectiveness in the understanding and processing of information on different levels, yet limited impact on language proficiency. Even though students did not believe that their ability to alternate between the two languages has placed them in a significantly enhanced comfort zone, it certainly, evident by their higher grades post-Translanguaging, enhanced their understanding and enabled them to achieve higher levels of knowledge processing. Clearly, Translanguaging addresses the students thinking skills, challenges them on many thinking levels until they "digest" the information and answer questions based on understanding not only repeating information. If used wisely in the classroom, and probably at certain times controlled by the instructor, Translanguaging could be a great asset to ESL classrooms and programs.

Despite the present time theoretical appraisal of L1 in learning foreign, second or additional languages, the target-language-only policy still dominates educators and policy makers worldwide, and more specifically in the Arab world (Li Wei, 2017), in particular, when the target language is a global language, such as English, perceived universally as a language that promotes communities' advancement.

Until educators and policy makers adopt a positive stance towards 'Translanguaging', embedding it in the course design wisely, its implementation as an ESL teaching and learning strategy would be far-fetched.

\section{Acknowlegments}

We would like to thank the students of the psycholinguistic course at the English department in The College of Basic Education. The project has been designed in January 2020. Yet, we had to put things on halt due to the closure of all colleges and schools in the country during Covid-19 pandamic. The completion of this research would not have been accomplished without their participation voluntarily in the various phases of the study's data collection via video conferencing and remote learning platforms. 


\section{References}

Akbar, R. (2018). Arabizi Among Kuwaiti Youths: Reshaping the Standard Arabic Orthography. International Journal of English Linguistics, 9(1), 301-323. https://doi.org/10.5539/ijel.v9n1p301

Alazmi, A (2017). Teaching of Academic Subjects in English and the Challenges Kuwaiti Students Face. PhD thesis. The University of Exeter. $\quad$ February 2017. https://ore.exeter.ac.uk/repository/bitstream/handle/10871/27997/AlazemiA.pdf?sequence=3\&isAllowed=n

Al-Bataineh, A., \& Gallagher, K. (2018). Attitudes towards translanguaging: How future teachers perceive the meshing of Arabic and English in children's storybooks. International Journal of Bilingual Education and Bilingualism, 1-15. https://doi.org/10.1080/13670050.2018.1471039

Alhawary, M. T. (2018). Routledge Handbook of Arabic Second Language Acquisition: Taylor \& Francis. https://doi.org/10.4324/9781315674261

Alrabah, S., Wu, S. H., Alotaibi, M., \& Aldaihani, H. A. (2015). English Teachers' Use of Learners' L1 (Arabic) in College Classrooms in Kuwait. English Language Teaching, 9(1), 1. https://doi.org/10.5539/elt.v9n1p1

Auer, P. (1999). From codeswitching via language mixing to fused lects toward a dynamic typology of bilingual speech. International Journal of Bilingualism, 3(4), 309-332. https://doi.org/10.1177/13670069990030040101

Baker, C. (2001). Foundations of bilingual education and bilingualism (3rd ed.). Clevedon, UK: Multilingual Matters.

ESTYN (2002). Framework for the Inspection of Schools. Cardiff: ESTYN. Fredman, S. (2000). Equality: A New Generation? Industrial Law Journal, 30, 145-168. https://doi.org/10.1093/ilj/30.2.145

Hassan, N., \& Ahmad, K. (2015). Exploring translanguaging: A case study of a madrasah in Tower Hamlets. Research In Teacher Education, 5(2), 23-28. DOI: 10.15123/PUB.4763

Creese, A., \& Blackledge, A. (2010). Translanguaging in the bilingual classroom: A pedagogy forlearning and teaching. The Modern Language Journal, 94, 103-115. https://doi.org/10.1111/j.1540-4781.2009.00986.x https://www.researchgate.net/publication/311519093_Translanguaging_as_a_Pedagogical_Tool_in_Multilingu al_Education [accessed Jul 28 2020].

Cummins, J. (1979). Linguistic Interdependence and the Educational Development of Bilingual Children. In Review of Educational Research, 49(2), 222-25. https://doi.org/10.3102/00346543049002222

Dashti, A. (2015). The role and status of the English language in Kuwait: How is English used as an additional language in the Middle East? English Today, 31(3), 28-33. https://doi.org/10.1017/S026607841500022X

García, O. (2009) Bilingual Education in the 21st Century: A Global Perspective. Oxford: Wiley-Blackwell, $45-54$.

Garcia, O., \& Wei, L. (2014). Translanguaging: Language, Bilingualism, and Education. New York, NY: Palgrave MacMillan, 162, 366-369. https://doi.org/10.1080/15235882.2014.965361

Kleyn, T., \& Garcia, O. (2019). Translanguaging as an Act of Transformation Restructuring Teaching and Learning for Emergent Bilingual Students. https://doi.org/10.1002/9781119421702.ch6

Krause, L., \& Prinsloo, M. (2016). Translanguaging in a township primary school: Policy and practice. Southern African Linguistics and Applied Language Studies, $347-357$. https://doi.org/10.2989/16073614.2016.1261039

Lewis, G., \& Baker, C. (2012). Translanguaging: origins and development from school to street and beyond. Educational Research and Evaluation, 18(7), 641-654. https://doi.org/10.1080/13803611.2012.718488

Li, W. 2011a. 'Moment analysis and translanguaging space: Discursive construction of identities by multilingual Chinese youth in Britain,' Journal of Pragmatics, 43, 1222-35. https://doi.org/10.1016/j.pragma.2010.07.035

Makoni S., \& Pennycook, A. (2007). Disinventing and reconstituting languages. https://doi.org/10.21832/9781853599255

https://books.google.com/books?hl=en\&lr=\&id=K2jTpJBQm0gC\&oi=fnd\&pg=PT7\&dq=Makoni+\%26+Penny cook,+2007\&ots=PkpX0X1PMu\&sig=Y_b-5iqdju9_oFe7U4EJdjK0MTg

Martin, H. E. (2005). Code-switching in US ethnic literature: multiple perspectives presented through multiple languages. https://doi.org/10.1080/13586840500347277

Mazak, C., \& Caroll, K. (2017). Translanguaging in Higher Education: Beyond Monolingual Ideologies. 
Translanguaging in Higher Education: Beyond Monolingual Ideologies, Mazak, C. M., \& Carroll, K. S. (Eds.) https://doi.org/10.21832/9781783096657

(2016). Buffalo, NY/Bristol, UK: Multilingual Matters, 208. https://doi.org/10.1080/15235882.2017.1421279

Nagy, N. (2017). Cross-Cultural Approaches: Comparing Heritage Languages in Toronto. Variation, 23(2). http://repository.upenn.edu/pwpl/vol23/iss2/12

Otheguy, R., Garcia, O., \& Reid, W. (2018). A translanguaging view of the linguistic system of bilinguals. Aplied Linguistic Review, 10(4). https://doi.org/10.1515/applirev-2018-0020

Palfreyman, D., \& Bataineh, A. (2018). 'This is my life style, Arabic and English': students' attitudes to (trans)languaging in a bilingual university context. Language Awareness, 27(1-2). https://doi.org/10.1080/09658416.2018.1431244

Park, M. S. (2013). Code-switching and Translanguaging: Potential Functions in Multilingual Classrooms. Teachers College, Columbia University Working Papers in TESOL \& Applied Linguistics, 13(2), 50-52. The Forum. https://journals.cdrs.columbia.edu/wp-content/uploads/sites/12/2015/04/3.6-Park-2013.pdf

Pennycook, A. (2010). Language as a Local Practice by Alastair Pennycook. London, England: Routledge, 2010, 174. 157-159. https://doi.org/10.1080/19313152.2011.594367.

Poza, L. (2017). Translanguaging: Definitions, Implications, and Further Needs in Burgeoning Inquiry. Berkeley Review of Education, 6(2), 101-128. https://doi.org/10.5070/B86110060

Smith, M. E. (1939). Some light on the problem of bilingualism as found from a study on the progress in mastery of English among pre-school children of non-American ancestry in Hawaii. Genetic Psychology Monographs, 21, 119-284.

Taqi, H. A., \& Shuqair, K. M. (2014). Evaluating the Students' Language Proficiency in the English Department, College of Basic Education in Kuwait. British Journal of Education, 2(6), 1-18.

Weinreich, U. (1953). Languages in contact. The Hague: Mouton.

Williams, C. (2002). Ennill iaith: Astudiaeth o sefyllfa drochi yn 11-16 oed [A language gained: A study of language immersion at 11-16 years of age]. Bangor: School of Education. https://www.researchgate.net/publication/311519093_Translanguaging_as_a_Pedagogical_Tool_in_Multilingua 1_Education

Yamat, H., Maroof, N., Maasum, T., Zakaria, E., \& Zainuddin, E. (2011). Teacher's code-switching as scaffolding in teaching content area subjects. World Applied Sciences Journal, 15(1), 18-22.

\section{Copyrights}

Copyright for this article is retained by the author(s), with first publication rights granted to the journal.

This is an open-access article distributed under the terms and conditions of the Creative Commons Attribution license (http://creativecommons.org/licenses/by/4.0/). 